\title{
David Hume's Notion of Personal Identity: Implications for Identity Construction and Affective Communal Living in Africana Societies
}

\author{
Lawrence Bamikole \\ University of the West Indies
}

The notion of personal identity is a topic that is widely discussed in all philosophical traditions-western, African, Asian, and Caribbean. The thread that runs through the different conceptions of personal identity is that the notion is linked with self-consciousness, whether in the metaphysical, epistemological, religious, or social contexts. In this paper, I shall focus attention on Hume's conception of personal identity drawing from it, and certain implications for affective communal life in Africana societies. It is a common knowledge among philosophers that Hume denies the ontological and independent existence of the self. For Hume, the self is a bundle of perception. However, in another section of the Treatise of Human Nature, Hume examines the development of what could be considered as self, placing it in a broad social context in which mirroring fellow minds have a critical role. What is significant in Hume's conception of personal identity is that the self is the locus of multifarious experiences and the social context in which it is placed enables us to relate the self to affective and relational construction of identity. It is then argued that this conception of identity can be used to stress the need for affection, love, compassion, sympathy, and empathy among persons, which in turn can promote societal transformation in Africana societies.

Keywords: David Hume, personal identity, affective community, sympathy and empathy, Africana societies

\section{Introduction}

Modern philosophy is characteristically egocentric. I mean no more than this: That firstly, it takes the self as its starting-point, and not God, or the world or the community; and that, secondly, the self is an individual in isolation, an ego, or "I" never as "thou." This is shown by the fact that there can arise the question, "How does the self know that other selves exist?" Further, the self so premised is a thinker in search of knowledge. It is conceived as the subject; the correlate in experience of the object presented for cognition. (Macmurray 1953, 31)

Somebody might want to suggest, contrary to the above claim, that Macmurry is guilty of over -generalization, and that he has used the model of Western philosophy to characterize philosophy in general. Thus it can be said that predominantly, traditional African societies are not egocentric, rather they are sociocentric. However, the truth of the matter is that slavery and colonialism and other effects of modernity have transmitted egocentric ideology to the enslaved and colonized societies such as that of Africa and its Diaspora societies.

Lawrence Bamikole, Ph.D., senior lecturer, Department of Language, Linguistics, and Philosophy, University of the West Indies, Jamaica; main research fields: Social and Political Philosophy, Ethics, and Africana Philosophy and Comparative Philosophy. E-mail:bamikolelawrence@yahoo.com. 
David Hume, whose philosophy is being considered in this paper, is a modern philosopher and this will suggest that the above characterisation of modern philosophy will apply to him. But is Hume's notion of personal identity egocentric? This question becomes important in virtue of the psychological and affective ingredients embedded in Hume's philosophy. Thus if a person (self) is marked by certain subjective features, it becomes important to inquire how a person so characterised can be related to another person who possesses similar characteristics. Therefore, two related questions which this paper seeks to respond to are: How does the self has the knowledge of other people's existence? If she has this knowledge, then how can such knowledge be used to relate significantly to other persons?

Now, it might be suggested that this question is not relevant in regards to the African traditional societies, given the fact that persons in those societies are predominantly not egocentric individuals and that the question can only arise within a post-colonial society in which the sociocentric individuals have been transmuted to an egocentric one with the attendant negative consequences on the general fabric of post-colonial Africana societies. However, to claim that African traditional societies are sociocentric does not suggest that there are no pockets of egocentricism among such societies. Thus it has been observed by Sprinzak $(1973,629)$ that the sociocentric thesis about traditional African societies does not square well with the empirically discoverable reality. This is because empirical research carried out by certain anthropologists, such as Kopytoff (1964) has discovered that some "African tribes were stratified, that they had developed different degrees of co-operation alongside individual ownership, and that they could not be said to be completely communal" (Sprinzak 1973, 629). However, the claim that is being made in this paper is that for analytical purposes, it is more theoretically appropriate to classify traditional African societies as sociocentric rather than egocentric because it distinguishes such societies from its Western counterparts that have been described as egocentric for the same analytical purposes. The issue will then arise as to how egocentricism can be replaced by sociocentricism, thereby returning African societies to the days of yore.

Another problem which this paper seeks to address is the conceptual problem that is unique to philosophy, especially, Western philosophy. The problem relates to how moral philosophy has been conceived and done within the Anglo-American tradition. In this tradition, moral philosophy is always conceived as a deliverance of reason (Kupperman 2002). According to Chemhuru (2014, 75), “A dominant feature of Western philosophical thinking has been the emphasis on the importance of human reason as informed by classical Socratic-Platonic and neo-platonic philosophies, philosophical realism, and the Cartesian philosophical traditions." What this means is that human reason should inform humanity on all fundamental moral issues. A corollary of this position is that morality is about choice and actors willing something consciously as an agent and trying to bring about certain situations which can be evaluated by means of certain rational principles and certain decision making procedures. However, this way of conceiving moral philosophy seems to overlook the affective/passive aspect of morality as it relates to the nature of the moral agent, where agents are also seen as capable of being moved by certain inner feelings to act morally that cannot ordinarily be subjected to rational evaluation.

It would be noted that Hume, among other modern philosophers, constitutes an exception to this way of doing moral philosophy. Hume pays attention to the role played by the emotions and the process of imagination in morality. David Hume has been credited with the view that reason is the slave to the passion and this has accounted for his being regarded as the modern precursor of moral psychology (Lennon 2010). Thus, in the Treatise of Human Nature, Hume discusses such notions as sympathy, love, hatred, joy, and grief. These 
represent the affective and emotional aspects of the human person. The question that arises is this: If these emotions are subjective experiences of the person (self) who has been conceived as atomic individuals, then it becomes difficult to see how the self can extend such emotions to others, given that such emotions are relational in nature. It is here that the problem of identity rears its ugly head and Hume presents an account of personal identity which is expected to address this problem.

Another way of putting the problem is that given the fact that the self is not the only existing entity (barring solipsism), how the self relates to another in such a way the passive emotions can be activated to a situation where they can be extended to the other, given the predominant view that other regarding is a purview of morality. Hume's response to this question relates to the role played by the imagination in morality. The way that Hume responded to this question reflects the application of his general philosophical doctrine of perception and the role which the human imagination plays in knowledge, especially moral knowledge.

The focus of this paper is therefore theoretical and practical. Its theoretical concern relates to the exploration from the perspective of Hume and other authors with similar perspectives of how the egocentric self can be transformed to a sociocentric one so that its subjective experiences can be shared with others and how the products of this transformation can be utilized to address the human condition in African and its Diaspora societies. However, before we address these concerns, we shall briefly discuss certain elements in Hume's philosophy which provides the groundwork for understanding these concerns.

\section{David Hume as a Modern Philosopher}

David Hume was a philosopher of many parts. He was a radical empiricist who was believed to have brought the doctrines of empiricism to its logical conclusion through the elimination of all metaphysical pretentions from the empiricism of Locke and Berkeley. Hume also had been accused of advocating a philosophy that was used to justify slavery and colonialism (Eze 1997). He was also regarded as a skeptic. Whatever the merits or otherwise of these positions, one thing is clear: There are certain insights in Hume's philosophy that can be used to respond to the human condition in whatever societies where human beings find themselves. This insight is that Hume's philosophy provides an avenue for understanding the human person and the relationship which exists between and among persons. Such understanding can aid the process of thinking about how persons can relate to one another in order to embark on activities that promote certain human virtues that are important for human and societal development.

Hume's philosophy derives from the fundamental distinction he makes between impressions and ideas. According to the distinction, impressions comprise "all our sensations, passions, and emotions, as they make their first appearance in the soul. Ideas are the faint images of these in thinking and reasoning" (O'Connor 1964, 256). Impressions and ideas, according to Hume, differ only in their strength and vivacity. Impressions and ideas together make what Hume calls perception. For Hume, impressions are antecedent to all ideas and there cannot be an idea without an antecedent impression.

The use to which Hume put this distinction had been responsible for labelling him as ironist in philosophy (Strawson 1977). For instance, Hume denied the existence of self as it was often understood from a common sense point of view; a view which saw the self as entity that persisted and subsisted through time. However, Hume thought that this was a piece of metaphysics which was a betrayal of the empiricist philosophy. In order to eliminate this metaphysical element in the idea of the self and thereby making empiricism consistent, Hume applied the famous dictum "that there is no idea without an antecedent impression." Thus in his conception of 
the notion of personal identity, Hume asked the question: From what impression could the idea of self derived? In order to give a proper answer to this question, it is necessary to quote Hume at some length:

It must be one impression that gives rise to every real idea. But self or person is not any one impression, but that to which out of several impressions and ideas are supposed to have reference. If any impression gives rise to the idea of self, that impression must continue invariably the same, through the whole course of our lives, since self is supposed to exist after that manner. But there is no impression constant and invariable. Pain and pleasure, grief and joy, and passions and sensations succeed each other and never all exist at the same time. It cannot therefore be from any of these impressions or from any other, that the idea of self is derived; and consequently there is no such idea. (Hume 1962, 301)

Hume, thereafter, went on to consider another question given the distinctness and separability of our impressions, how they are connected to give an intelligible understanding of the self. His famous answer is: "For my part, when I enter most intimately into what I call myself, I always stumble on some particular perception or other of heat or cold, light or shade, love or hatred, and pain or pleasure. I never can catch myself at any time without a perception, and never can observe anything but the perception" (Hume 1962, 301). On the basis of these distinctions, Hume came up with his view of personal identity (self) as: "The self is nothing but a bundle or collection of different perceptions which succeed each other with an inconceivable rapidity and are in a perpetual flux and movement (Hume 1962, 301).

It has been thought that Hume's conception of personal identity as discussed above represents a denial of the ontological and independent existence of self. However, in another section of the Treatise (Book II Part II Section V), Hume examines the development of what could be considered as self, placing it in a broad social context in which "mirroring fellow minds have a critical role" ( Kupperman 2010, 195). The way which Hume develops this idea is the concern of the next section of the paper.

\section{Hume and the Role of Imagination in Morality}

As it is pointed out in the introductory section of this paper, Hume occupies an important place in moral philosophy in the sense that he is among philosophers who are willing to consider the place of emotions and imagination in morality. Thus Hume is able to base his moral theory on certain distinctive human attributes like emotions and imagination. The problem here, which we shall defer to an appropriate section of the paper, relates to whether this way of conceiving and doing ethics runs foul of Moore's naturalistic fallacy and the blurring of the is/ought distinction.

From this perspective of understanding Hume's moral theory, Ferreira $(1994,39)$ observed that Hume's theory of morality embodied reference to universality by making reference to certain qualities that bind human beings together. Thus Hume talked about, appealing to the "universal principle of the human frame," the "particular fabric and constitution of the human species," and the "original constitution of the mind." In relation to morality, the dimension of this human constitution is expressed in such words as "feeling," "sentiment," "internal sense," and "heart," and they are manifested through "sympathy." Thus the principle of "sympathy" provides a privileged access to Hume's understanding of ethical imagination" (Ferreira 1994, 40).

What is important in the above characterization of Hume's notion of sympathy is that it suggests universality in the sense that irrespective of culture and exhibits emotional feelings, chief of every human being is the feeling of sympathy. Here, sympathy is contrasted with self-love which is an egoistic notion and given the fact that sympathy is an extension of the self to the other, it is a notion that is other-regarding. Thus, given Hume's conception of self as a locus of multiple and multifarious identities, he suggests that the impression of 
self is capable of generating an idea of the other and converting this idea into an impression that is vivid and vivacious. In other words, passive emotions like love and sympathy can be activated by means of the imagination and extended to other persons. Ardal observed that Hume thought that sympathy worked in the following way:

The idea of ourselves is always intimately present to us, and it conveys a sensible degree of vivacity to the idea of any other subject to which we are related. This lively idea changes by degrees into a real impression; these two kinds of perception are in a great measure the same, differing only in their degree of force and vivacity. $(1966,43)$

Hume's account of sympathy brings to the fore many philosophical issues. Some of these issues are epistemological, metaphysical, and meta-psychological. One of the epistemological issues relates to how subjective experiences can be converted into inter-subjective ones such that solipsism would be transcended. The metaphysical issue concerns the notion of identity as it is commonly conceived. According to that view, identity individuates and separates one person from another and it is logically impossible for one person to be another person. The meta-psychological issue concerns the nature of the process through which a person can "enter" into another person in order not only to understand his/her emotional state but also absolve his/her feelings and make them as his/her own.

How does Hume address these philosophical issues in relation to the notion of sympathy? For Hume, sympathy is always an imaginative extension of ourselves, even when it is to feel the present sentiments of others. We may illustrate what Hume is saying in this way: Here is a person close to me that is materially poor-she cannot satisfy her basic needs - she cannot eat, nor clothe, nor house herself. Sympathy gives a lively notion of all her circumstances, whether in past, present, or future. The idea of these morbid conditions is converted to a lively impression in me and I am interested in them, engage in them, and feel a sympathy motion in my heart. Given the fact that the self is made up of multiple identities, I am able to convert her conditions and make them my own, thereby identifying myself with her in all situations relevant to her condition. But can I also have sympathy for a distant other that is a person who is not close to me? Hume's analysis seems to accommodate this question. This is because through watching video pictures or listening to the news, a person might imagine the situation of certain persons in far away Somalia, which is ravaged by war and poverty, or Syria and South Sudan where civilians are being massacred, and by means of imagination, she is moved by sympathy to feel certain unsavoury conditions that such distant persons are experiencing. This imagination and sympathetic feelings are possible because they are universal features possessed by human beings that enable them to have feelings for one another, whether such persons are close or distant (Hanfling 1993).This process of imagination is similar to Descartes' conception of passion, as the "assent by which we consider ourselves henceforth as joined with what we love in such a manner that we imagine a whole, of which we take ourselves to be only one part, and the thing loved to be the other" (Soble 2008, 32)

This account of human imagination as evinced in the notion of sympathy has a logic of its own, which has been referred to as "affective logic" (Lennon 2010). According to Lennon, human perception has an imaginary dimension which suggests that the perceived world has a physiognomy, in which elsewhere is woven in to the "present." This suggests that human perception is not only exclusively subjective and along with our subjectivity, there is a realm of the "other" which goes beyond our immediate perception. This means that the "other" is required in the process of making a sense of our own modes of existence. An affective logic therefore reinforces Hume's idea that sympathy belongs to the affective domain of human existence and there might be 
situations when human beings can be moved by that emotion in such a way that we see the need to reach out to others.

What may be learnt from Hume's notion of sympathy is that it is a feeling that transcends the egoistic self and recognizes the existence of other persons outside oneself. This is an outcome of Hume's conception of personal identity, a conception that has been shared by philosophers across different intellectual traditions. However, the gap in Hume's notion of sympathy relates to how sympathetic feelings can be converted to action, such that the person who is the object of sympathy could be helped out of her condition. In other words, how does the feeling of sympathy generate an obligation from the rich to help the poor? Before we can attend to this question, it is necessary to acknowledge that some other philosophers have shared Hume's views about the self and its relationship to the other.

William James (1890) just like Hume before him held that the self is not a unitary phenomenon. James held a multiple conception of the self, and according to that conception, the self should be viewed as both empirical and metaphysical. The empirical self is made up of the material self, the social self, and the spiritual self, whereas the metaphysical self is the pure ego. As a naturalist (pragmatist), James was agnostic about the pure ego, claiming that there may be metaphysical reasons for accepting the pure ego, but this would carry us beyond the psychological or naturalistic point of view. The material self is made up of body, clothes, family, and home. In this category of the self, James was echoing Locke (2000) who held the view that a person owns himself/herself absolutely and whatever belongs to him/her is a product of his/her labour. The social self is a category of self that a person shares with another person. For James, a person's social self is the recognition which he/she gets from another. A person has many social selves as there are individuals who recognize him/her and carry an image of her/him in their minds. Finally, the spiritual self should be viewed in terms of psychic dispositions or faculties. Examples given by James are our ability to argue and discriminate our moral sensibility and conscience and our indomitable will. James went further to suggest that there was a hierarchy of selves - the merely bodily at the lowest and the spiritual at the highest with the social in the middle. It has to be noted that the spiritual and the social domains of the self in James's account correspond to the Humeannotion of sympathy in the sense that it is the category of the self that is called forth by the acts of others.

Abolilafia (2008) has observed that for aspect of Jamesian self, there is a potentiality for growth for a widening of the self that requires us to forgo immediate rewards, which Hume refers to as self love. Thus the social self is the most interesting by reason of its connection with our moral and religious life. The problem engendered by James's analysis is similar to the one we allude to earlier-this is the problem of the connection between the psychic self and the social self. How do Hume and James address the problem, such that the seeming tension between the two is dissolved? One of the ways of responding to this question is to explore issues related to sympathy as social and moral virtue.

\section{Sympathy as an Ethical and Social Virtue}

What we want to explore in this section is the problem of how our subjective experiences and our passion can be activated to generate objective inter-subjective states of affairs. Another way of putting the question is that how our passion generates obligation to another person such that our psychic self can be extended to the social self. Hume's response here is that persons' minds mirror one another not only because they reflect each other's emotions, but also because those rays of passions, sentiments, and opinions, may be often reverberated and may decay away by insensible degrees. 
However, we may observe here that Hume's response does not adequately respond to the questions that are posed here. For instance, it can be asked: How does one person's mind mirror the mind of another person? What is the epistemic status of the word "mirroring?" One may sympathize with Hume's position here because he is a victim of a predominant tradition in Western philosophy which often sees concepts and phenomena as opposed to one another. Concepts have been defined in such a way as to create conceptual gulf between them. Thus, Hills (2004) holds that there is a dualism of practical reason between egoism and utilitarianism because each picks out different right making characteristics. While egoism talks about the maximization of the agent's happiness, utilitarianism speaks about maximizing every one's happiness. Even Kantian Categorical Imperative generates dualism of practical reason because it enjoins us to treat all persons, including ourselves as ends and not as means only. It must be noted that African philosophy is immune to this way of philosophizing because it does not believe in the type of dualism that is responsible for the current problem we are trying to address here. In this connection, Okolo (1992) has observed that self in African philosophy is socially consisted and there is no dichotomy between self and others given the sociocentric conception of the self.

Okolo's view represents the pre-dominant view among some African scholars that the ontological basis of African conceptual scheme revolves round Father Tempels' notion of "vital force" as expressed in Bantu Philosophy (Imafidon 2014; Chemhuru 2014). The notion of a "vital force" implies a principle of the connectedness of all entities based on common essence and a principle of harmony based on the organic solidarity and complementary of all forms (Imafidon 2014, 39). This position suggests that the usual dichotomy between concepts as evinced in Western thought system is lacking in African belief system and as such the gulf between self and others that creates the problematic in Hume's philosophy is none existent.

However, the problem alluded to earlier in relation to the gulf between the self and others, such that inner feelings like sympathy can generate obligation from one person to the other, has been addressed within the Western system of thought. One of such attempts is that of Searle (2001). Searle distinguishes between strong and weak altruism. Weak altruism is where a person is naturally inclined to care about the interests of others. This is termed "weak" altruism because it is grounded in nothing more than a disposition or preference. On the other hand, a strong altruist (the one that generates obligation) is a person who recognizes the interests of others as a valid reason for acting even in cases where he/she has no such inclination. Baggini $(2002,449)$ has summarized Searle's argument in three steps: (I) Searle requires us to accept that when we say, "I am in pain," we are committed by the generality requirement to recognize that in a similar situation you would be in pain; (II) My pain creates a need and I am in pain so I need help; (III) My need for help is a reason for others to help me.

The insight in Searle's argument is that although there is a gap between self and others, such a gap can be bridged by the public nature of the use of certain words and terms. For instance, a linguistic community perfectly understands the word "pain" and the mental events brought about by it. Since all human beings are capable of experiencing pain, we can have the feeling of what it entails to be in pain. A person that is in pain certainly requires help to mitigate it which suggests that he/she is in need. Now, the word "need" is not only an empirical word, rather than that it is value-laden. Searle refers to such words as "institutional facts" (Searle 1964). Institutional facts are capable of generating social obligation given the fact that they function as performative utterances that are understood by a given linguistic community. Such utterances are believed to be linked to certain social actions and as long as persons understand what these utterances mean, they will, as a matter of convention, carry out the action picked out by such utterances. Certain philosophical problems still exist in relation to Searle's account, but we think his account is capable of shedding light on how the gap 
between an agent and others can be bridged and therefore how subjective persons can be activated to generate obligations. In the final section of this paper, we shall attempt to apply this reconstruction of Hume's philosophy along with the African belief in the interconnection among persons, brought about by the ontology of "vital force" to the idea of an affective community in Africana societies.

\section{Hume's Notion of Personal Identity and Affective Community in Africana Societies}

There is no point belabouring the fact that most Africana societies are experiencing certain unsavoury existential situations that are economic, political, and social. These situations border on the human condition in such societies. There is prevalence of poverty in various dimensions, youth unemployment, crimes of different dimensions, illiteracy and the decline of basic infrastructures, and leadership deficit at all levels of societal organisations. These problems have led to labelling such societies as underdeveloped. Scholars have attributed these indices of underdevelopment to the influences of slavery and colonialism, the process of modernization, and the type of relationship between the so called "developed" and "underdeveloped" nations of which Africa and its Diaspora societies are exemplifications of the latter. Whatever the merits or otherwise of this position, attempts have been made to address these problems. What it is being suggested in this paper is that certain hints from Hume's conception of personal identity and the implications that it engenders can be used to address the problem of the deficit of human relationship in which post-colonial Africana societies have found themselves. The problem is how certain attributes of human beings (here sympathy) can be harnessed to generate an obligation on certain persons, groups of persons, and the leadership in Africana societies to mitigate the problems faced by certain others - the vulnerable and the needy. Like Hume, a person who can have a feeling of sympathy is the one that has experienced first-hand the condition of another person. In Hume's terminology, this person has an impression that is so lively, which touches her heart. For example, a person that has experienced material poverty is likely to have sympathy for the poor more than anybody who has not experienced poverty. Late Moshood Abiola, a former business guru, whose election to the presidency in Nigeria in 1993 is annulled by the military, readily comes to mind here. It is widely believed that Late Moshood Abiola came from a very poor family in a situation where he required fending for himself at an early age. Through dint of hard work, Abiola rose from grass to grace to become one of the successful businessmen in Nigerian history. The fact that Abiola experienced poverty first-hand left him with the feeling that poverty is painful and as such any person who finds himself/herself in the situation of poverty deserves some sympathy. This might have resulted in his philanthropic gestures to the poor around him and also others that are not so close to him. Hume's position also accommodates a situation in which if somebody has not even experienced poverty firsthand, she is capable of imagining poverty, given the fact that as a human being, she has a feeling of sympathy running through her veins and she is capable of converting this idea to an impression and thereby sharing this feeling with the other. By the same token, a person that has experienced conditions of unemployment may be moved to sympathize and consider giving or creating jobs for the unemployed. A person that has experienced the pain of losing her loved one to a murderer will likely refrain from committing murder, given the fact that she/he could imagine the anguish that will accompany the loss of a loved one. Somebody who has a late opportunity to be educated who eventually is educated will likely have a sense of sympathy for the uneducated. This was the case of Late Chief Obafemi Awolowo, the former Premier of Western Region in Nigeria, whose history was told that he was educated late in life and that at a time he was selling firewood to raise funds for his educational training. Awolowo later bagged the LLB Degree by correspondence. Chief Awolowo realized that 
certain obstacles prevented him to become what he wanted to become. He knew that these conditions were present in his society and felt an obligation to remove them and consequently, he introduced Free Education to address the problem of illiteracy. Most of today's elites in Nigeria were products of Free Education introduced by Awolowo. Finally, a leader that has experienced the implications of lack of basic infrastructures like light and good roads is likely to be moved by the emotion of sympathy to put herself under an obligation to provide these amenities.

Our position here is similar to Martha Nussbaum's (1996) account where, according to Carr $(1999,419)$ "she undermines the dichotomy between emotion and reason which she achieves by stressing the rich cognitive dimension of compassion and the depiction of compassion as contributing to the enrichment of social life in the major areas of political leadership, welfare planning, legal reasoning, and public institutions." The crucial question here is whether and how this can be actualized in practice. This will be the focus of the last section of the paper

\section{The Praxis of Sympathy as a Human Virtue}

One of the challenges confronting philosophy as an academic discipline relates to its public perception as a discipline that has little or nothing to contribute to practical affairs. Even when Russell (2001) has referred to this attitude as "the practical man syndrome," the attitude dies hard.

In responding to this challenge, many African scholars have revisited the nature of philosophy that has been bequeathed to us by Western scholarship, especially its Anglo-American aspect. Such position sees philosophy as critical, analytic, and argumentative. Philosophy, according to this view, can only be done by technical persons that are trained philosophers within the academia, and it does not so much matter whether the outcomes of their research activities are applicable to what obtains in the wider society.

However, given the situation in African and its Diaspora societies, where a chunk of the national budget is being allocated to fund Higher Education, African scholars do not have the luxury of doing research that is not practically relevant to the development of their societies. This is a debate that will take us beyond the focus of this paper. However, it suffices to note that as philosophers, we have the obligation to offer solutions to pressing economic, social, and political problems that bedevil our society which does not allow its people to fulfill their legitimate life goals. In the rest of the paper, we shall suggest how Hume's notion of sympathy can be of practical relevance to the process of transforming relationship among the people who inhabit the continent of Africa and its Diaspora societies.

Within current practices in many African and Caribbean universities, there are various attempts to domesticate philosophy through different approaches like seminars, conferences, and outreaches. It is believed that through these avenues, the public could be sensitized to acknowledge the utility of philosophy. The question is that how this could be done and our suggestion is that it could be done through public education.

In relation to this paper, the type of education that is required to bring human activities in conformity with certain human virtues is like that sympathy requires a change in the mind-set of the Africana people; the change of attitude is from the current egocentricism which colonialism and modernity have wrought in their societies to the sociocentric one that requires that persons should always be their brothers' and sisters' keepers. The education required for this purpose is a moral one generated by affection from one person to the other. This will be in line with Hume and the African rejection of the view that morality is exclusively a deliverance of reason. This moral education is the kind of education, which according to Gbadegesin (2014) could be identified with 
the tradition of a given people. According to him, moral tradition is identified with the customary institution of moral beliefs, moral rules, moral principles, and moral judgments, from which moral problems and moral issues develop from time to time for individuals and the group respectively. Moral tradition in the sense of a moral life is a habit of affection (our emphasis) and conduct. It involves no serious reflection: We generally behave in accordance with the tradition from which we were brought up (Gbadegesin 2014, 4).

Our position then is that transmission and actualisation of the virtue of sympathy in Africana societies should be based on education predicated on concrete life situations where persons have imbibed certain human virtues through education that is driven by public enlightenment. The education needed here is not only the formal but the non-formal as well. In this case, there is a need for collaborative effort. This collaboration will see philosophers working together with psychologists, sociologists, community leaders, and governmental and non-governmental agencies, to sensitize the society about the need to extend sympathy to one another by appropriate behaviours and attitudes. The social media will also have a great role to play in transmitting these virtues. However, by and large, Africana leaders at all levels have the responsibility of re-enacting Africana societies and instituting structures that will encourage wholesome human relationship among persons in these societies, which in turn can transform African and its Diaspora societies from their present morbid social situations to a progressive one that can guarantee human flourishing in all ramifications.

\section{Conclusion}

What we have done in this paper is to reflect upon implications of Hume's theory of personal identity, with the aim of applying them to address some of the problems of the human condition in African and its Diaspora societies. This, in our opinion, is one way of making philosophy relevant to the understanding of human beings as agents living in human societies, pointing out the grounds of the responsibilities they have to do for one another. We recognize the fact that persons in post-colonial Africana societies have had their belief system modified by the institutions of slavery, colonialism, and the phenomenon of modernity; our position in this paper is that the current behaviours, attitudes, and institutions in such societies can be made to undergo modification for the better by philosophical arguments that appeal to an often neglected aspect of the human person - the emotions, by using such arguments as tools for effecting attitudinal changes among the peoples in Africana societies. Rather than seeing emotion as always irrational and exclusively subjective, it has been shown that they are important cohorts of human imagination that can drive persons towards recognizing the fact that they are obliged to one another in the bid for their fulfilment of their individual and collective goals. This is the lesson we have learnt from Hume's notion of sympathy as a human emotion which requires imagination to activate it thereby making it relevant within the context of human societies in general and Africana societies in particular.

\section{Works Cited}

Aboulafia, Mitchell. "W. E. D. Du Bois: Double Consciousness, Jamesian Sympathy, and the Critical Turn." The Oxford Handbook of American Philosophy. ed. Cheryl Misak. Oxford: Oxford University Press, 2008. 169-84.

Ardal, Pall S.. Passion and Value in Hume's Treatise. Edinburgh: Edinburgh University Press, 1966.

Baggini, Julian. “ Morality as a Rational Requirement.” Philosophy 77 (2002): 447-53.

Carr, Brian. "Pity and Compassion as Social Virtues." Philosophy 74 (1999): 411-29. 
Chemhuru, Munamato. "The Ethical Import in African Metaphysics: A Critical Discourse in Shona Environmental Ethics." Ontologized Ethics: New Essays in African Meta-Ethics. eds. Elvis Imafidon \& John Ayotunde Isola Bewaji. United Kingdom: Lexington Books, 2014. 73-88.

Ferreira, M. Jamie. "Hume and Imagination: Sympathy and 'the Other.'” International Philosophical Quarterly XXXIV (1994): 39-57.

Gbadegesin, Segun. "Moral Traditions and Moral Revolution: A Conceptual Analysis." Ontologized Ethics: New Essays in African Meta-Ethics. eds. Alvis Imafidon and John Ayotunde Isola Bewaji. Lexington: Lexington Books, 2014. 1-13.

Herman, Barbara. "Reasoning to Obligation.” Inquiry 49 (2006): 44-61.

Hills, Alison. “Is Ethics Rationally Required?” Inquiry 47 (2004): 1-19.

Hanfling, Oswald. "Loving My Neighbour, Loving Myself.” Philosophy 68 (1993): 145-57.

Hume, David. A Treatise of Human Nature, Book I. D. D. C.. ed. Oxford: Fontana Books, 1962.

Imafidon, Elvis. "On the Ontological Foundation of a Social Ethics in African Tradition." Ontologized Ethics: New Essays in African Meta-Ethics. eds. Elvis Imafidon and John Ayotunde Isola Bewaji. United Kingdom: Lexington Books, 2014. $37-54$.

James, William. The Principle of Psycholology. NY: Dover Publications, 1890.

Kopytoff, Igor. "Socialism and Traditional African Societies." African Socialism. eds. W. H. Friedland \& C. G. Rosberg. Great Britain: Stanford Press, 1964. 53-62.

Kupperman, Joel J.. "Why Ethical Philosophy Needs to Be Comparative.” Philosophy 85 (2010): 185-200.

Kupperman, Joel J.. “A Messy Derivation of the Categorical Imperative.” Philosophy 77, 302 (2002): 485-502.

Lennon, K.. "Re-enchanting the World: The Role of Imagination in Perception.” Philosophy 85, 333 (2010): 375-89.

Locke, John. "Two Treatises on Government." William Ebenstein and Alan Ebenstein, eds. Great Political Thinkers: Plato to the Present. USA: Wadswoth, 2000. 380-407.

Macmurry, John. The Self as Agent. London: Faber and Faber Limited, 1953.

Nussbaum, Martha. “Compassion: The Basic Social Emotion.” Social Philosophy and Policy 13 (1996): 27-58.

O’Connor, D. J.. A Critical History of Western Philosophy. NY: The Free Press, 1964.

Okolo, Chukwudum B.. "Self as a Problem in African Philosophy.” International Philosophical Quarterly XXXII (1992): $477-85$.

Russell, Bertrand. The Problems of Philosophy. Oxford: Oxford University Press, 2001.

Searle, J. R.. "How to Derive Ought from Is." Philosophical Review LXXIII (1964): 43-58.

Searle, J. R.. Rationality in Action. Cambridge, Massachusetts: The MIT Press, 2001.

Soble, Alan. The Philosophy of Sex and Love. NY: Paragon House, 2008.

Sprinzak, Ehud. "African Traditional Socialism—a Semantic Analysis of Political Ideology." The Journal of Modern African Studies 11.4 (1973): 629-47.

Strawson, P. F. Individuals: An Essay in Descriptive Metaphysics. London: University Paperbacks, 1977. 